\title{
MEMBANGUN EKONOMI PASCA COVID 19 DI DESA SADAH TANAH MERAH BANGKALAN MELALUI PELATIHAN PEMBUATAN KERIPIK KELAPA
}

\author{
Tri Wahyudi Ramdhan. Junaidi, Kholil Baita Putra
}

STAI Darul Hikmah Bangkalan

wahyudi@darul-hikmah.com, junaidialmuchtar@darul-hikmah.com,

\section{kholil@darul-hikmah.com}

\begin{abstract}
ABSTRAK
Implikasi Covid 19 membuat masyarakat banyak mengalamai penuruan bahkan kehilangan pemdapatan. Salah satu cara yang dapat dilakukan untuk memulihkan aktivitas ekonomi masyarakat terutama di desa Sadah dengan cara mengembangkan inovasi dari potensi lokal masyarakat. Kegiatan pengabdian ini dilakukan melalui tahap persiapan pelaksanaan program dengan melakukan koordinasi dan sosialisasi yang dilaksanakan kepada masyarakat. Sedangkan tahapan proses pelaksanaan program dilakukan melalui workshop di masing-masing dusun yang ada di Desa Sadah.. Luaran pemgabdin ini adalah produk yang dihadilkan masyarakat Desa sadah dalam memgolah keripik kelapa. Diharapkan dari olahan kripik kelapa yang memiliki nilai jual lebih sehingga dapat memulihkan perekonomian masayarakat Desa Sadah.
\end{abstract}

Kata kunci-Membangun ekonomi, covid 19, keripik kelapa,

\begin{abstract}
The Covid 19 effect has made many people experience a decrease and even loss of income. One way that can be done to restore the economic activities of the community, especially in Sadah village, is by developing innovations from the local potential of the community. This service activity is carried out through the preparatory stage for program implementation by coordinating and conducting socialization to the community. Meanwhile, the program implementation process stage is carried out through workshops in each hamlet in Sadah Village. The output of this local government is a product that is brought by the Sadah Village community in processing coconut chips. It is hoped that the processed coconut chips will have more selling value so that they can restore the economy of the people of Sadah Village.
\end{abstract}

Keywords - Building the economy, covid 19, coconut chips, 


\section{A. ANALISIS MASALAH}

Desa sadah adalah salah satu desa di Kecamatan Galis, Kabupaten Bangkalan Madura.. Desa sadah memiliki luas sebesar 4.41 $\mathrm{Km}^{2}$ demgan struktur geografis yang sulit akses air bersih. Desa Sada memiliki kepadatan penduduk 654,20 per $\mathrm{km}^{2}$ yang mana sebagian besar penduduknya adalah perantau. (BPS Bangkalan 2018)

Desa Sadah dalam sektor pertanian dan perkebunan memiliki topografi yang cocok untuk ditanami tanaman kelapa. Tanaman kelapa banyak dijumpai disetiap kebun bahkanndi setiap rumah warga. Hal ini menjadikan kelapa sebagai potensi yang seharusnya dapat dioptimalkn menjadi produk unggulan desa

Padahal, Kelapa (cocos nucifera) adalah salahbsatu komoditi yang dapat memiliki nilai ekonomi tinggi. Hal ini dikarenakan pohon kelapa mulai dari buah, daun dan batangnya dapat dimanfaatkan (Hamka, 2012). Produk tanaman kelapa, jugavmenjadi komoditi ekspor yang dapat meningkatkan devisa negar. Buah kelapa merupakan sumber minyak dan lemak nabati yang bagus (Subagio, 2011).

Selain airnya, daging kelapa menjadi bagian paling pemting dari beberapa bagian pohon kelapa. Sehingga sangat disayangkan bila bagian buah kelapa tidak dimaksimalkan oleh para pendudik Desa Sadah. Buah kelapa di Desa Sadah, selama ininhanay dimanfaatkan sebagai bahan baku minuman kelapa muda. Hal ini menjadikan kelapa tidak berhasil mendistribusikan nilai tambah secara ekonomi telebibi pasca Covid 19.

Implikasi pamdemi Covid 19 yang saat ini masih belum usai berimbas kepada perekonomian masyarakat Desa Sadah. Sebagian besar masyarakat Desa Sadah adalah perantauan yang mana pandemi ini mereka harus berupaya mencari alternatif pekerjaan. Dan salah satu solusi 
Bermulai daribtitik ini, tujuan program pengabdian kali ini salah satunya adalah pembuatan kripik kelapa. Kreasi produk ini dibuat dari daging buah kelapa yang, renyah dan manis serta mempunyai bau khas (Rizky \& Mavianti, 2019). Kreasi kripik dari olahan buah kelapa dapat dikonsumsi sebagai makanan ringan sehingga nempunyai nilai ekonomis yang lebih tinggi dari pada hanya dijual buahnya saja.

Program pengabdian kepada masyarakat kali ini, diimplementasikan sebagai upaya dalam mengedukasi masyarakat desa Sadah Selain itu, program pengabdian kepada masyarakat ini diharapkan bisa menjadi ssrana pemukihan perekonomian sa Sada oasca Covid 19.

\section{B. METODE}

Mekanisme implementasi program pengabdian kepada masyarakat ini dilaksanakan melalui pemberdayaan masyarakat pada bidang ekonomi dengan pelatihn dan pendampingan pembuatan keripik kelapa. Metode pelaksanaan program pelatihan dan pendampingan pembuatan keripik kelapa terdiri dari persiapan progrm, riset pasar dan formulasi produk, serta strategi marketing.

Pada tahap persiapan pelaksanaan pelatihan dan pendampingan program dimulai dengan observasi potensi desa dengan melluii sumber daya alam unggulan Desa Sadah. Metode observasi dilakukan melalui sekaligus berkonsultasi langsung dengan kepala desa Sadah untuk mengetahui peluang usaha, tantangan, bahan baku dan pemasaran yang dimiliki.

Tahoan kedua adalah proses uji coba pembuatan keripik kelapa. Pada tahap ini dilakukan pula riset peluang pangsa pasar dalam mencari serta memastikan supplier bahan baku yang diperlukan. Selain itu 
dilakukan pula analisis tantangan dalam menjalankan usaha ini. Uji coba ini juga diperuntukkan dalam formulasi komposisi bahan baku yang seimbang sehingga dapat menciptakan ciptarasa unggul.

Selanjutnya adalah tahap pelaksanakan pelatihan dan pendampingan program. Tahapn ini dilaksanakan mellui workshop pada masing-masing dusun di Desa Sadah. Masyarakat juga diedukasi tentang oljan pojon kelapa yang mana tidak hanya digunakan untuk memasak semata, tetapi juga dapat dijadikan produk olahan yang memiliki nilai ekonomis yang tinggi.

Selain itu, dilaksankan pula pelatihan tentang strategi pemasaran produk olahan kripik kelapa. Pada pelatihan ini, para peserta diberikan edukasi tentang sistem marketing secara online. Strategi online marketing strategy ini adalah segala usaha yang dilakukan dalam menjajakan produk atau jasa menggunakan media internet. Strategi online dipilih karena dirasa lebih efektif dan efisien dalam mengurangi promotion cost. Selain itu, strategi ini akan lebih kuas jangkauan pemasaran oroduknkepada konsumen dibanding sistem yang lain

Berikut adalah tahapan metode program pelatihan dan pendampingan pemberdayaan dapat dilihat pada Gambar 1 berikut.

\section{Gambar 1.}

Tahapan Metode pelatihan dan pendampingan pembuatan keripik kelapa

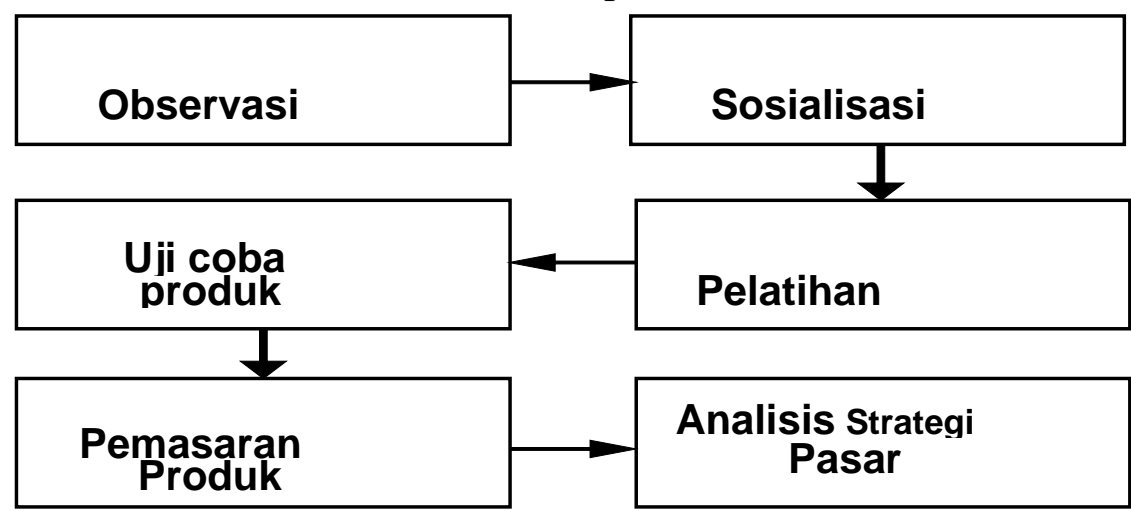




\section{HASIL DAN PEMBAHASAN}

Untuk menghasilkan suatu produk tentunya diperlukan beberapa tahap yang harus dilakukan. Tahap awal yang dilakukan dalam pelaksanaan program ini adalah pendampingan pelatihan pembuatan keripik kelapa kepada masyarakat Desa Sadah. Kegiatan pendampingan ini diawali dengan koordinasi dan sosialisasi yang dilaksanakan kepada masyarakat, serta menentukan jadwal pelaksanaan pendampingan pelatihan pembuatan keripik kelapa. Hal ini dimaksudkan supaya jumlah masyarakat Desa Sadah yang bisa mengikuti sosiali lebih banyak jumlahnya.

\section{Gambar 2.}

Proses koordinasi dengan pihak masyarakat sebelum pelaksanaan

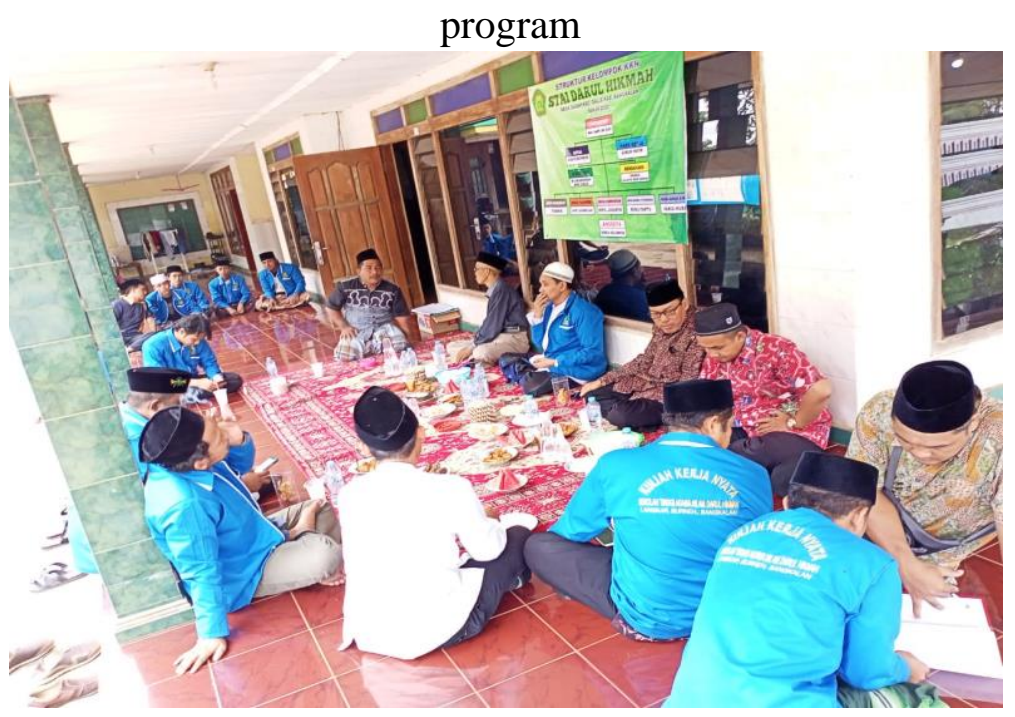

Sosialisasi awal terkait program pemberdayaan ekonomi pasca bencana melalui pelatihan pembuatan keripik kelapa dalam forum terbuka sangatlah penting dilakukan terlebih dahulu sebelum tahapan proses lainnya. Hal tersebut bertujuan untuk: Pertama, guna mengedukasi masyarakat dalam mengenali potensi alam terbesar yang 
ada di desanya serta mengolahnya dengan optimal. Kedua, mengedukasi masyarakat terkait pemanfaatan potensi alam yang melimpah untuk diinovasikan menjadi produk bernilai jual tinggi. Tujuan lainnya yakni untuk menciptakan peluang usaha melalui olahan produk lokal yang memiliki ciri khas yang mana kedepan diharapkan dapat menjadi produk unggulan desa.

Gambar 3.

Proses pemaparan materi di kegiatan ini

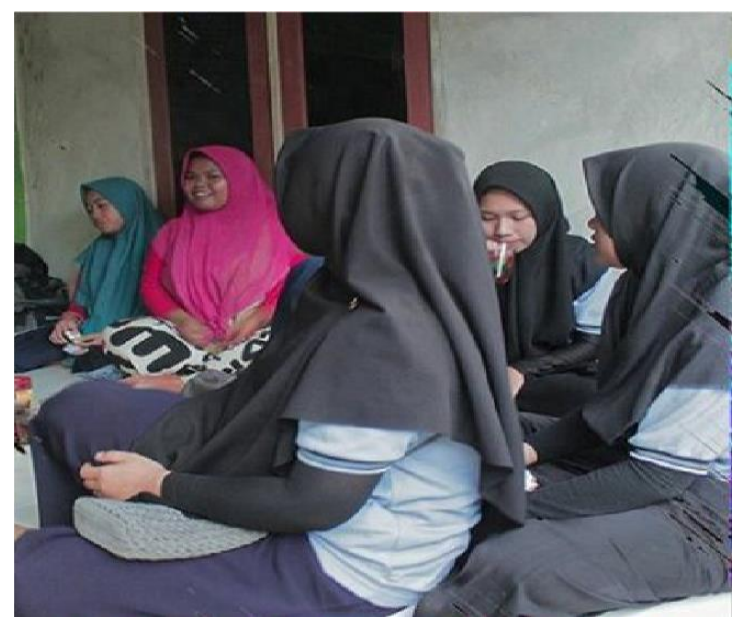

Kegiatan pelatihan ini dilaksanakan secara berkala di setiap dusun yang ada di Desa Sadah. Selama kurang lebih 3 minggu, pelatihan diberikan kepada kelompok ibu-ibu. Adapun proses dalam pendampingan pelatihan ini meliputi pemilihan buah kelapa yang kepalem (tidak terlalu muda dan juga tidak terlalu tua). Proses perajangan kelapa menggunakan alat perajang. Kemudian, proses pengeringan dalam proses ini bisa dioven agara hasil pengringannya maksimal atau juga dapat dijemur dengan bantuan panas matahari. sedangkan proses pembuatan adonan kripik dengan takaran bahanbahan yang sesuai, cara penggorengan yang baik agar menghasilkan 
keripik yang bentuknya menarik, dan dapat membuat keripik yang renyah dan gurih.

Hasil produksi dari pelatihan tersebut nantinya akan dipergunakan sebagai sampel penjualan yang akan diperjualkan di warung-warung kelontong yang ada di desa, serta diperjualkan di obyek wisata maupun untuk pasar modern sekaligus BUMDES (Badan Usaha Milik Desa).

Kemudahan dalam pelatihan pembuatan keripik kelapa semakin dirasakan ketika proses merajang kelapa dipermudah dengan adanya bantuan alat perajang kelapa secara manual yang disediakan di masingmasing dusun. Efisiensi waktu juga dapat dirasakan, diawali dengan pemberian arahan ibu-ibu yang mengikuti pelatihan sangat tanggap, yakni tercipta pembagian tugas dalam pelaksanaannya baik yang merajang ataupun yang membuat adonan hingga proses penggorengan. Ibu-ibu semakin tertarik lagi setelah mencicipi hasil keripik kelapa yang telah dipraktekkan secara langsung.

\section{Gambar 4.}

Proses perajangan kelapa dengan alat pelajang

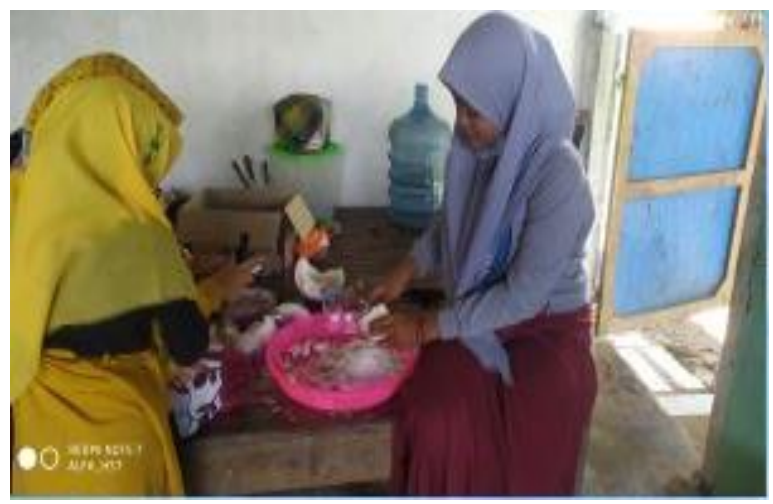

Pelatihan pembuatan keripik kelapa oleh ibu-ibu PKK telah menumbuhkan rasa percaya diri di antara anggota. Bahkan ada sebaian 
peserta berniat untuk dijadikan sebagai inovasi baru dalam menambah produk usaha sendiri dirumah masing-masing

Dari pelaksanaan program kegiatan pendampingan masyarakat Desa Sadah menghasilkan suatu produk yakni mengolah kelapa muda menjadi keripik kelapa sebagai inovasi sumber daya lokal desa yang berdaya saing, serta dapat meningkatkan daya jual kelapa muda yang merupakan potensi unggulan di Desa Sadah.

Produk keripik kelapa ini memiliki beberapa keunggulan, antara lain: 1) Tidak mengandung bahan pengawet, karena dalam proses pembuatan keripik kelapa menggunakan bahan-bahan alami yang tidak mencampurkan dengan bahan kimia, 2) Memiliki citarasa yang khas, cita rasa khas disini yaitu karena berasal dari rasa asli buah kelapa yaitu gurih, dan 3) Terdapat beberapa varian rasa di dalam keripik kelapa, tidak hanya varian asli original tetati rasa dari produk keripik kelapa ini yaitu balado, jagung manis, dan barbeque dimana varian rasa tersebut menambah daya tarik konsumen untuk membelinya.

Selain memberikan pelatihan pembuatan keripik kelapa, dilaksankan pula pemberian pelatihan mengenai strategi marketing product. Dalam pemasaran produk keripik kelapa ini lebih memanfaatkan media sosial. Strategi pemasaran online (online marketing strategy) merupakan segala bentuk usaha yang berkaitan dengan bisnis guna memasarkan suatu produk ataupun jasa melalui media online yakni internet (Setiawati \& Widyartati, 2017). Namun, tidak hanya dilakukan pemasaran saja. Dalam dunia kewirausahaan perlu diadakannya suatu proses branding agar produk memiliki nilai jual tinggi dimata para konsumen. Branding dipilih dengan cara memberikan merk pada produk keripik kelapa. Kegiatan ini bertujuan 
untuk memasarkan produk keripik kelapa agar dikenali oleh masyarakat luas.

\section{Gambar 5.}

Packing produk kripik kelapa Desa Sadah

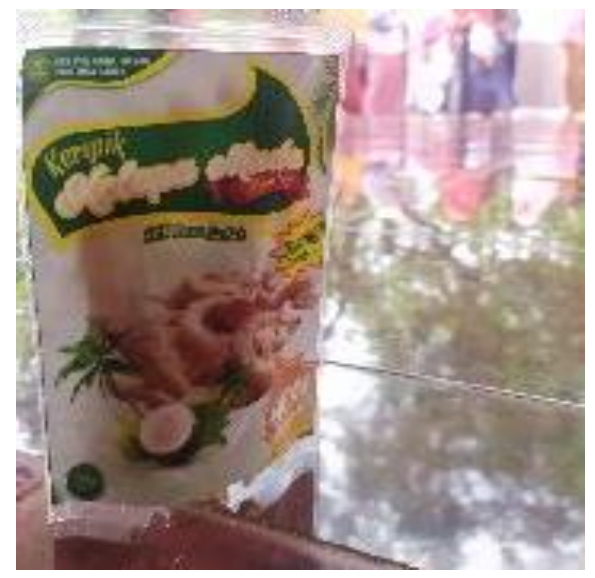

Kebermanfaatan dari program kegiatan ini adalah untuk mengetahui bahwa adanya produk keripik kelapa tersebut dapat dijadikan sebagai upaya pemulihan ekonomi pasca bencana di desa Sadah. Semula buah kelapa yang tidak dimanfaatkan secara maksimal dan hanya dijadikan sebagai santan, tetapi sekarang bisa dijadikan olahan keripik kelapa yang salah satunya dapat meningkatkan pendapatan masyarakat desa Sadah.

\section{KESIMPULAN}

Melalui pelaksanaan program pendampingan pembuatan keripik kelapa yang dilaksanakan di Desa Sadah ini dapat diketahui bahwa kegiatan ini dapat digunakan sebagai salah satu alternatif dalam upaya peningkatan kapasitas masyarakat di bidang ekonomi dengan memanfaatkan hasil alam yakni kelapa yang diolah menjadi keripik kelapa. Selain memberikan pendampingan pelatihan pembuatan keripik kelapa, diadakan pula pelatihan mengenai strategi online 
marketing sebagai edukasi strategi pemasaran keripik kelapa yang akan digunakan kedepannya.

Keripik kelapa merupakan peluang bisnis baru di Desa Sadah. Usaha ini memiliki peluang yang cukup besar dikarenakan belum adanya UKM (Usaha Kecil Menengah) yang membuat produk ini sebelumnya. Diharapkan, usaha inibdapat memberikan dampak positif bagi oerekonomin masyarakat desa Sadah pasca Covid 19.

Kegiatan ini bisa terus dilanjutkan dengan menggunakan inovasiinovasi yang lebih terbarukan. Tentunya pangsa pasar dari produk ini tidak hanya masyarakat sekitar tetapi juga bisa lebih luas lagi hingga ke luar provinsi. Sehingga pendapatan masyarakat Desa Sadah juga semakin meningkat pasca Covid 19. 


\section{DAFTAR PUSTAKA}

Emrizal. (2015). Pemulihan Ekonomi Dengan Usaha Mikro Pasca Gempa Dan Tsunami Tahun 2009 Di Sumatera Barat. SNEMA-2015, 81-86. Hamka, H. (2012). Analisis faktor produksi tanaman kelapa (Cocos nucifera) terhadap pendapatan petani. Agrikan: Jurnal Ilmiah Agribisnis dan Perikanan, 5(1), 49. https://doi.org/10.29239/j.agrikan.5.1.4956

Negoseno. (2003). Reinventing Agribisnis Perkelapaan Nasional. Ditjen Bina Produksi Perkebunan, 17-27.

Rizky, R. N., \& Mavianti. (2019). Keripik Kelapa: Peluang Usaha Baru di Dusun 3 Tanjung Anom, Deli Serdang. Prosiding Seminar Nasional Kewirausahaan, I(1). https://doi.org/10.30596/snk.v1i1.3633

Setiawati, I., \& Widyartati, P. (2017). Pengaruh Strategi Pemasaran

Online Terhadap Peningkatan Laba UMKM.Bingkai Manajemen, 5.

Subagio, A. (2011). Potensi Daging Buah Kelapa sebagai Bahan Baku Pangan Bernilai. Jurnal Pangan, 20(1), 12.

Wulandari, E., \& Zubaidah, E. (2016). Kebab Bakso Bakar: Inovasi Kuliner Khas Kota Malang Menjadi Modern Sebagai Upaya Pelestarian Kuliner Bangsa. 4(1), 8 . 